\title{
Quantifying the Finest Particles in Dust Fractions Created During the Sanding of Untreated and Thermally Modified Beech Wood
}

\author{
Jerzy Majka, ${ }^{a}$ Maciej Sydor, ${ }^{\mathrm{b}, *}$ Marta Pędzik, ${ }^{\mathrm{c}, \mathrm{d}}$ Petar Antov, ${ }^{\mathrm{e}}$ L’uboš Krišt’ák, ${ }^{\mathrm{f}}$ \\ Richard Kminiak, ${ }^{\mathrm{g}}$ Martin Kučerka, ${ }^{\mathrm{h}}$ and Tomasz Rogoziński ${ }^{\mathrm{d}}$
}

\begin{abstract}
This article deals with the fractionation of wood dust by sieve after sanding. Dust from untreated beechwood was compared to dust from thermally modified beechwood (at $200{ }^{\circ} \mathrm{C}$ for $3 \mathrm{~h}$ ). The authors hypothesized that the thermal modification changes the particle size distributions of the dust sieve fractions and that all the dust sieve fractions contain the finest particles, which are suspendable in the air and are potentially respirable. To obtain dust for testing, both wood materials were sanded with P120 paper at a belt speed of $14.5 \mathrm{~m} / \mathrm{s}$ and a pressure of $0.65 \mathrm{~N} / \mathrm{cm}^{2}$. A set of sieves with aperture sizes of 25,80 , and $250 \mu \mathrm{m}$ were used to separate the dust into sieve fractions with grain sizes less than $25 \mu \mathrm{m}, 25$ to $80 \mu \mathrm{m}$, 80 to $250 \mu \mathrm{m}$, and greater than $250 \mu \mathrm{m}$. The content of the finest particles in the fractions was measured via a laser particle sizer. Both dusts had similar particle size distributions. In addition, each investigated fraction of both dusts contained the finest particles, i.e., less than $10 \mu \mathrm{m}$. It follows that the laser analysis method may be necessary to correctly assess the occupational risk at a sanding.
\end{abstract}

DOI: 10.15376/biores.17.1.7-20

Keywords: Sieve analysis; Laser diffraction methods; Particle-size distribution; Sanding; Occupational risk; ANOVA

Contact information: a: Poznań University of Life Sciences, Faculty of Forestry and Wood Technology, Department of Wood Science and Thermal Technics, Wojska Polskiego 38/42, Poznań 60-637 Poland; b: Poznan University of Life Sciences, Faculty of Forestry and Wood Technology, Department of Woodworking and Fundamentals of Machine Design, Poznań 60-637 Poland; c: Łukasiewicz Research Network, Wood Technology Institute, Poznań 60-654 Poland; d: Poznań University of Life Sciences, Faculty of Forestry and Wood Technology, Department of Furniture, Poznań 60-624 Poland; e: University of Forestry, Faculty of Forest Industry, Department of Mechanical Wood Technology, Sofia 1756

Bulgaria; f: Technical University in Zvolen, Faculty of Wood Science and Technology, Department of Physics, Electrical Engineering and Applied Mechanics, Zvolen 96001 Slovakia; g: Technical University in Zvolen, Faculty of Wood Science and Technology, Department Woodworking, Zvolen 96001 Slovakia; h: Matej Bel University, Faculty of Natural Sciences, Banská Bystrica 97409 Slovakia;

*Corresponding author: maciej.sydor@up.poznan.pl

\section{INTRODUCTION}

Heat treatment is a process for changing the physical properties of wood and the appearance of its surface (Olek et al. 2013; Pelaez-Samaniego et al. 2013). Thermally modified wood has reduced volumetric mass density, changed hygroscopicity and flammability, increased biological resistance, and improved dimensional stability (Osvaldová and Osvald 2013; Gašparík et al. 2017; Čermák et al. 2021; Makovicka Osvaldova et al. 2020). Furthermore, woodworking energy consumption is advantageously 
reduced (Kubš et al. 2016). However, some strength properties are deteriorated, making the wood more fragile (Blokland et al. 2020). Gluing thermally modified wood is usually more difficult than gluing untreated wood (Vidholdová et al. 2021). In addition, due to changes in the chemical structure resulting from the effects of elevated temperatures, the wood acquires a darker color, which makes it more attractive (Dudiak 2021). During the heat treatment of wood, no chemicals are used, so it is not toxic and does not pose a threat to the environment. Non-toxicity, improved properties, and a more attractive appearance are the primary reasons for the increased use of thermally treated wood (Candelier and Dibdiakova 2021).

Wood dust, which creates atmospheric particulate matter, is dangerous to human health (Pędzik et al. 2020). Particles resulting from the woodworking of thermally modified wood may have different properties from particles made from untreated wood. These wood particles may be finer and therefore more susceptible to being airborne for a longer period of time, as well as being a respirable fraction, possibly posing a serious threat to human health.

Kučerka and Očkajová (2018) studied the properties of the dust created during the sanding of thermally modified wood from sessile oak (Quercus petraea) and Norway spruce (Picea abies). The test results showed that the lowest values of the dust fraction, with a size of less than or equal to $0.08 \mathrm{~mm}$, were obtained at a processing temperature of $220{ }^{\circ} \mathrm{C}$ for both species. In the case of oak, the highest amounts of dust were obtained from the $32 \mu \mathrm{m}$ fraction. The authors stated that the increase in the treatment temperature did not affect the amount of dust generated. The authors explained that the high amount of dust created during sanding was due to the decreased wood density resulting from the increased temperature during the modification process.

Očkajová et al. (2019) examined the relationship between the density of three species of wood, i.e. sessile oak (Quercus petraea), Norway spruce (Picea abies), and Meranti (Shorea acuminata), subjected to thermal modification and the amount of dust created as a result of sanding the wood. The amount of thermally modified oak dust particles that were less than or equal to $80 \mu \mathrm{m}$ was similar to the amount of untreated wood at $92 \%$ to $95 \%$. A considerable decrease in the amount of these particles was recorded only at $220{ }^{\circ} \mathrm{C}$. The largest amount of dust with a size less than or equal to $80 \mu \mathrm{m}$ for other species was determined at a temperature of $160^{\circ} \mathrm{C}$ and decreased as the modification temperature increased (approximately $87 \%$ for meranti and $93 \%$ for spruce). Therefore, the increase in temperature reduced the amount of wood dust particles formed when sanding spruce, oak, and meranti wood, separated in the smallest sieve $(32 \mu \mathrm{m})$ and at the bottom of the screening machine, and increased the number of larger particles. The results of the granular analysis were similar, primarily due to the decreased density of the thermally modified wood, which confirmed the results of the previous research (Hlásková et al. 2018).

Očkajová et al. (2020b) subjected the thermally modified oak and pine wood dust generated during longitudinal milling with a ZDS-2 spindle milling machine to a granulometric analysis. In the case of both tested wood species, it was observed that the higher the modification temperature, the greater the amount of small-sized dust particles. This relationship was compared to dust from the sanding process, and the analysis of the residue curves showed that this relationship was inverse. Residue curves for the sanding dust were shifted toward the particles with a smaller amount in the dust fractions as the wood modification temperature increased for both species. The largest share of the fine fraction, i.e., less than or equal to $80 \mu \mathrm{m}$, was recorded for spruce ( $84 \%$ to $93 \%)$. Also 
based on previous studies on oak sanding dust, it can be concluded that the fraction amounts with a particle size less than or equal to $80 \mu \mathrm{m}$ was high when sanding various wood species and ranged between $85 \%$ and 95\% (Marková et al. 2016; Očkajová et al. 2018).

Očkajová et al. (2020a) studied the particle size distribution of thermally modified spruce and oak wood particles formed during longitudinal milling on a ZDS-2 low-spindle milling machine. The authors stated that the amount of coarse, fine, and very fine dust fractions increased as the wood modification temperature increased. Furthermore, the amount of particularly hazardous dust, that is, less than or equal to $80 \mu \mathrm{m}$, increased in oak, but only occurred in spruce after applying a considerably increased temperature, that $i s, 200{ }^{\circ} \mathrm{C}$ and $220{ }^{\circ} \mathrm{C}$. Particles less than or equal to $32 \mu \mathrm{m}$ were obtained in very small quantities.

The analysis performed by Kminiak and Dzurenda (2019) showed that more than two thirds of the maple (Acer pseudoplatanus L.) wood particles produced during milling on a 5-axis CNC machining center were coarse-grained fractions, i.e., greater than $100 \mu \mathrm{m}$. The amount of particles with a size smaller than $125 \mu \mathrm{m}$ did not exceed $2.5 \%$. The milling of thermally treated maple wood did not form the finest dust fraction, which meant that it would not have a negative impact on the environment or human health. The results obtained did not confirm the thesis suggested by the earlier authors that changes that cause an increased amount of fine dust fraction occur as a result of the heat treatment on the chemical structure of wood.

The results of research by various authors suggest that thermal modification contributes to the reduction of the dust fraction from milling and sawing with a particle size less than or equal to $80 \mu \mathrm{m}$-(Dzurenda et al. 2010; Očkajová et al. 2020a; Očkajová et al. 2020b). However, in scientific publications on the dust generated during sanding thermally modified wood (oak, spruce, meranti), based on the sieve analysis performed, a lower content of particles with the smallest size was found in the dust from the wood modified at the highest temperature $\left(220^{\circ} \mathrm{C}\right)$ (Kučerka and Očkajová 2018; Očkajová et al. 2019). The absence of the finest particles, that is less than $32 \mu \mathrm{m}$, was also found by Kminiak and Dzurenda (2019).

Such statements are in contradiction with the research results described by Hlaskova et al. (2018). These authors, based on the results of the sieve analysis, found that the increased modification temperature of beech wood resulted in a reduced content of the smallest particles in the dust resulting from sanding. However, in the dust from wood modified at higher temperatures, the microscopic image analysis showed a much higher finest particle content. The use of the laser diffraction analysis method to assess the finest particle content in the under-sieve fraction (containing the smallest particles) also allowed the conclusion that when modified pine wood was milled, the modification temperature influenced the finest particle content in the resulting dust, causing it to increase (Piernik et al. 2019).

The occurrence of the smallest particles suspended in the air was also investigated. Such particles, with dimensions smaller than $10 \mu \mathrm{m}$, were found during the sawing of and unmodified and thermally modified aspen, fir, maple, ash, and poplar. The thermal modification of wood did not affect the amount of these particles in the air (Aro et al. 2019).

As is well known, the sieving method has limitations, as its accuracy decreases with particles smaller than $100 \mu \mathrm{m}$, with a mixture of particles of different specific weights, with a mixture of particles prone to agglomeration, e.g., with increased moisture content, when containing resin or adhesive, or susceptible to triboelectric charging, with non- 
spherical particles, e.g., of elongated shape, or with brittle particles.

The purpose of this research was to characterize the dust fractions generated from sanding untreated and thermally modified beech wood and determine the finest dust particle content with sizes less than $10 \mu \mathrm{m}$ in all dust fractions, separated by sieve analysis using the laser diffraction method.

\section{EXPERIMENTAL}

\section{Materials}

European beech (Fagus sylvatica L.) wood was selected as a test material. The wood heat treatment included the following: an initial phase in moist air followed by heating in superheated steam after the temperature reached $130{ }^{\circ} \mathrm{C}$, a maximum heating phase (at a temperature of $200{ }^{\circ} \mathrm{C}$ for $3 \mathrm{~h}$ ), and a cooling phase with superheated steam followed by cooling in moist air only. The thermal modification method was consistent with the method described in the ThermoWood ${ }^{\circledR}$ Handbook (ThermoWood 2021). The wood dust was created with a small belt sander (Cormak, Siedlce, Poland) with a horizontal abrasive belt arrangement and P120 sandpaper with dimensions of $1000 \mathrm{~mm} \times 80 \mathrm{~mm}$. A belt speed of $14.5 \mathrm{~m} / \mathrm{s}$ and a pressure of $0.65 \mathrm{~N} / \mathrm{cm}^{2}$ were applied. The wood sanding parameters were identical to those in earlier publications (Pędzik et al. 2020; Sydor et al. 2021; Pędzik et al. 2021). Planks with a width equal to the width of the belt were used. The dust generated during sanding was collected using a large polyethylene bag (so all dust was collected, i.e. settled dust and airborne dust).

\section{Methods}

The particle size analysis and the calculation of the fine dust particle content were performed using the methods described by Hlásková et al. (2015), Rogoziński et al. (2015), and Piernik et al. (2019). Sieve analysis was performed using a laboratory sieving machine (AS 200, Retsch, Germany) with a set of sieves with apertures of $25 \mu \mathrm{m}, 80 \mu \mathrm{m}$, and $250 \mu \mathrm{m}$ (the sieve apertures were successively three times larger than each other). As a result of the sieve analysis, four dust fractions were obtained: less than $25 \mu \mathrm{m}, 25$ to 80 $\mu \mathrm{m}, 80$ to $250 \mu \mathrm{m}$, and greater than $250 \mu \mathrm{m}$. The size fraction less than $25 \mu \mathrm{m}$ was the smallest sieve fraction, the $25-80 \mu \mathrm{m}$ fraction contained particles that passed through an $80 \mu \mathrm{m}$ aperture size sieve but were retained by a $25 \mu \mathrm{m}$ sieve, the $80-250 \mu \mathrm{m}$ fraction contained particles sieved through a $250 \mu \mathrm{m}$ sieve but retained by an $80 \mu \mathrm{m}$ sieve, and the fraction greater than $250 \mu \mathrm{m}$ were particles retained by a $250 \mu \mathrm{m}$ sieve. The mean arithmetic particle sizes were calculated according to Eq. 1,

$$
\bar{x}=\sum_{i=1}^{n} x_{i} \cdot q_{3 i}
$$

where $q_{3}$ is the particle distribution by mass, $x$ is the mean value of the particle size class, and $n$ is the number of particle classes.

Three sieve factions were taken for verification of the finest particle content: less than $25 \mu \mathrm{m}, 25$ to $80 \mu \mathrm{m}$, and 80 to $250 \mu \mathrm{m}$. The greater than $250 \mu \mathrm{m}$ fraction was not tested, because it contained particles larger than $2000 \mu \mathrm{m}$, which are outside of the measuring range of the laser particle sizer. The finest particle contents, i.e., with sizes less than $2.5 \mu \mathrm{m}$, less than $4 \mu \mathrm{m}$, and less than $10 \mu \mathrm{m}$, were measured using an Analysette 22 Microtec Plus laser particle sizer (Fritsch, Germany). This instrument measures the lengthrelated equivalent diameters of dust particles. Particles of this size can easily suspend in 
the air and are then can be inhaled and therefore by dangerous to human health (BeljoLučić et al. 2011).

\section{Statistical Analysis}

A multivariate analysis of variance (ANOVA) was performed to test whether thermal modification (a), sieve aperture size (b), or particle size (c) had an effect on the finest particle content in the dust sieve fraction from beech wood. The post hoc HSD Tukey test was used to test the significance of differences between the average particle size of the dust from untreated (control) and thermally modified beech wood as well as the content of less than $2.5 \mu \mathrm{m}$, less than $4 \mu \mathrm{m}$, and less than $10 \mu \mathrm{m}$ dust particles in the dust fractions of the sieve. Significance was established with a p-value of less than 0.05 . The statistical significance of the differences in the average content of the smallest particles in the tested fractions of the two types of dust (untreated and thermally modified beech wood) was shown with superscripts a and b. Identical superscripts represent non-significant differences between the analyzed values. The experimental data was statistically analyzed using STATISTICA 13.3 software (TIBCO Software Inc., Palo Alto, CA).

\section{RESULTS AND DISCUSSION}

\section{Sieve Analysis Results}

The results of the dust fractionation via sieve analysis for the two tested wood materials are presented in Fig. 1. The comparison of the fraction masses showed that the dust produced from the unmodified wood had a structure similar in size to that of the thermally modified wood dust. The mass of the 25 to $80 \mu \mathrm{m}$ fraction, calculated by Eq. 1, was $31.5 \%$ of the mass of the untreated wood dust, while for modified wood dust, the mass was slightly higher (38.4\%). However, the 80 to $250 \mu \mathrm{m}$ fraction represented $57.2 \%$ (dust from unmodified wood) and $51.7 \%$ (thermally modified wood) of the mass, respectively. Moreover, dust from thermally modified wood had a slightly higher mass fraction of $<25$ $\mathrm{m}(6.6 \%)$ compared to the dust generated during sanding modified wood (6.1\%). The mean arithmetic particle size, calculated by Eq. 1, was $58.14 \mu \mathrm{m}$ for unmodified wood dust and $58.17 \mu \mathrm{m}$ for modified wood dust. Therefore, the use of sieve analysis with this particular set of sieves did not allow the determine the difference in the average dimensions of the dust particles formed during the sanding of the untreated and thermally modified beech wood.

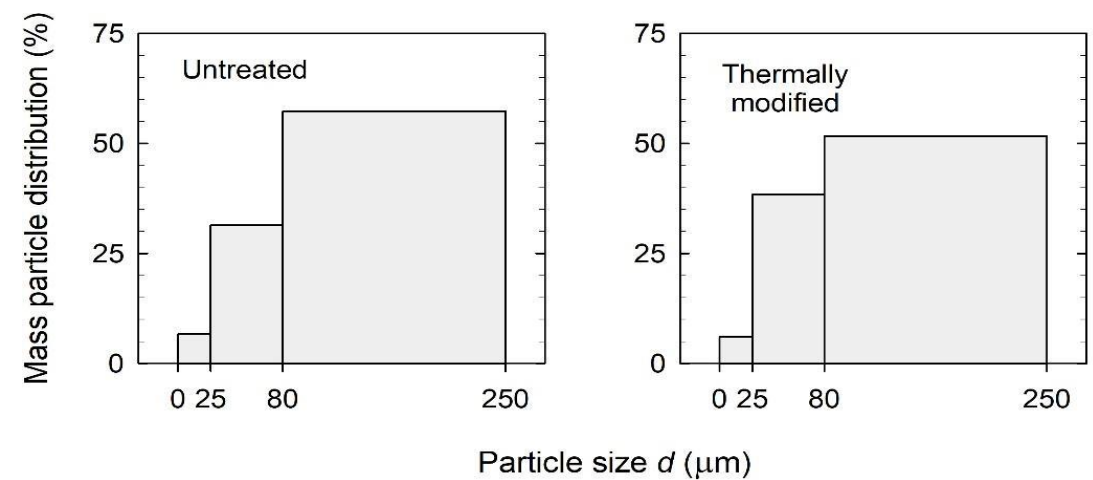

Fig. 1. Particle size distribution of the untreated and thermally modified beech wood dust via the sieve analysis method 


\section{Laser Analysis Results}

A comparison of the cumulative and frequency distributions of the untreated and thermally modified beech wood dust, measured by laser diffraction analysis, is presented in Fig. 2. The finest particles (smaller than the aperture size) were found in the 25 to 80 $\mu \mathrm{m}$, and 80 to $250 \mu \mathrm{m}$ sieve fractions. Particles with dimensions smaller than $10 \mu \mathrm{m}$, smaller than $4 \mu \mathrm{m}$, and even smaller than $2.5 \mu \mathrm{m}$ were found. They were identified in the three dust fractions analyzed previously separated by the sieve method (as shown in Fig. 2 ). This demonstrates that the use of the laser analysis method is valuable to correctly assess the level of occupational risk at a workstation equipped with a wood sander.
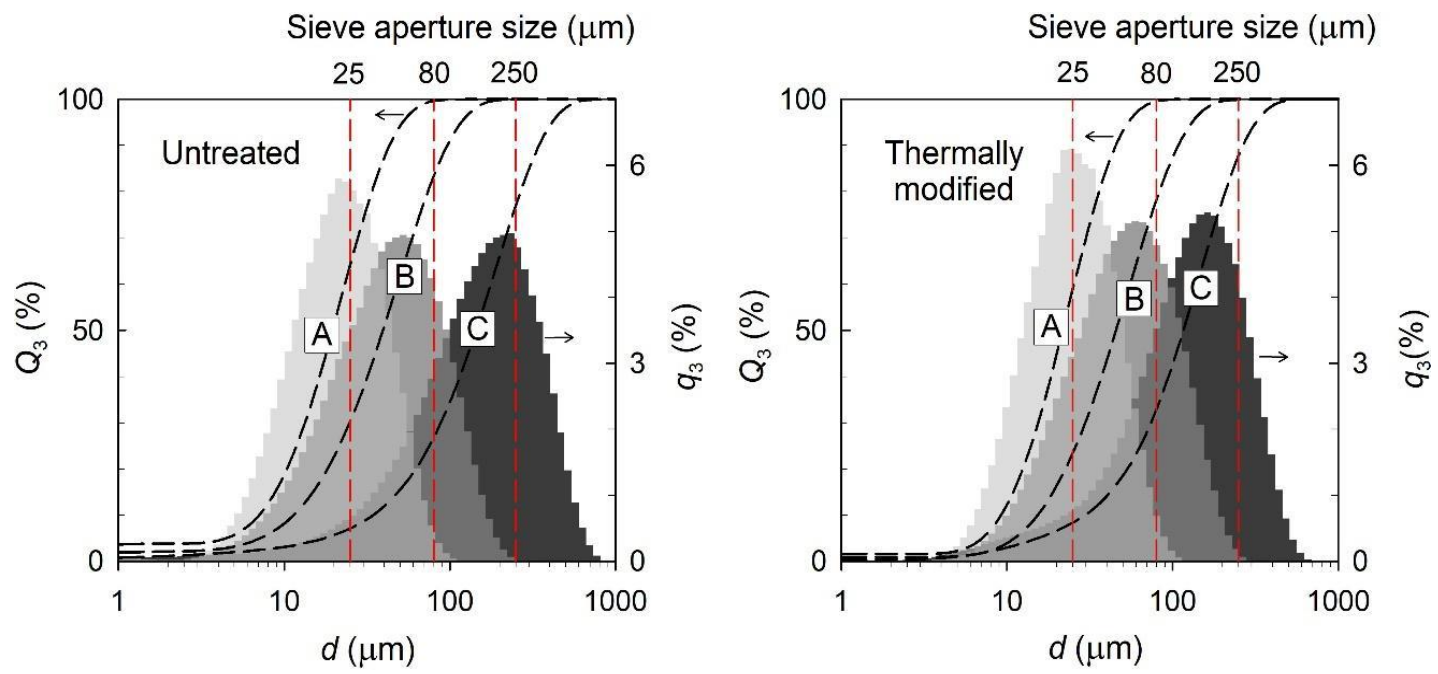

Fig. 2. Cumulative particle size distribution $\left(Q_{3}\right)$ and particles frequency distribution $\left(q_{3}\right)$ of the untreated and thermally modified beech wood dust fractions: $A$ is less than $25 \mu \mathrm{m}$; $B$ is $25 \mu \mathrm{m}$ to $80 \mu \mathrm{m}$; and C is 80 to $250 \mu \mathrm{m}$ (Note: Red dashed line is the sieve aperture size)

\section{The Results of the Variance Analysis}

The results of the variance analysis (ANOVA) for the particle size distribution of the untreated and thermally modified beech wood dust are presented in Table 1.

Table 1. Analysis of Variance (ANOVA) for the Particle Size Distribution of the Untreated and Thermally Modified Beech Wood Dust with Respects to the Effects of the Heat Treatment, Sieve Aperture Size, and Particle Size

\begin{tabular}{|c|c|c|c|c|c|}
\hline Effect & SS & df & MS & F-value & p-value \\
\hline Intercept & 137.39 & 1 & 137.39 & 173.92 & 0.0000 \\
\hline Heat treatment (a) & 0.72 & 1 & 0.72 & 0.92 & 0.3418 \\
\hline Sieve aperture size (b) & 65.05 & 2 & 32.52 & 41.17 & 0.0000 \\
\hline Particle size (c) & 174.06 & 2 & 87.03 & 110.16 & 0.0000 \\
\hline $\mathrm{a} \times \mathrm{b}$ & 0.65 & 2 & 0.33 & 0.41 & 0.6629 \\
\hline $\mathrm{a} \times \mathrm{c}$ & 1.70 & 2 & 0.85 & 1.07 & 0.3473 \\
\hline $\mathrm{b} \times \mathrm{c}$ & 98.14 & 4 & 24.54 & 31.06 & 0.0000 \\
\hline $\mathrm{a} \times \mathrm{b} \times \mathrm{c}$ & 1.10 & 4 & 0.27 & 0.35 & 0.8452 \\
\hline Error & 52.14 & 66 & 0.79 & - & - \\
\hline
\end{tabular}

Note: $S S$ is the sum of squares; $d f$ is the degrees of freedom; $M S$ is the mean squares; and $F$ is the Fisher`s F-test 

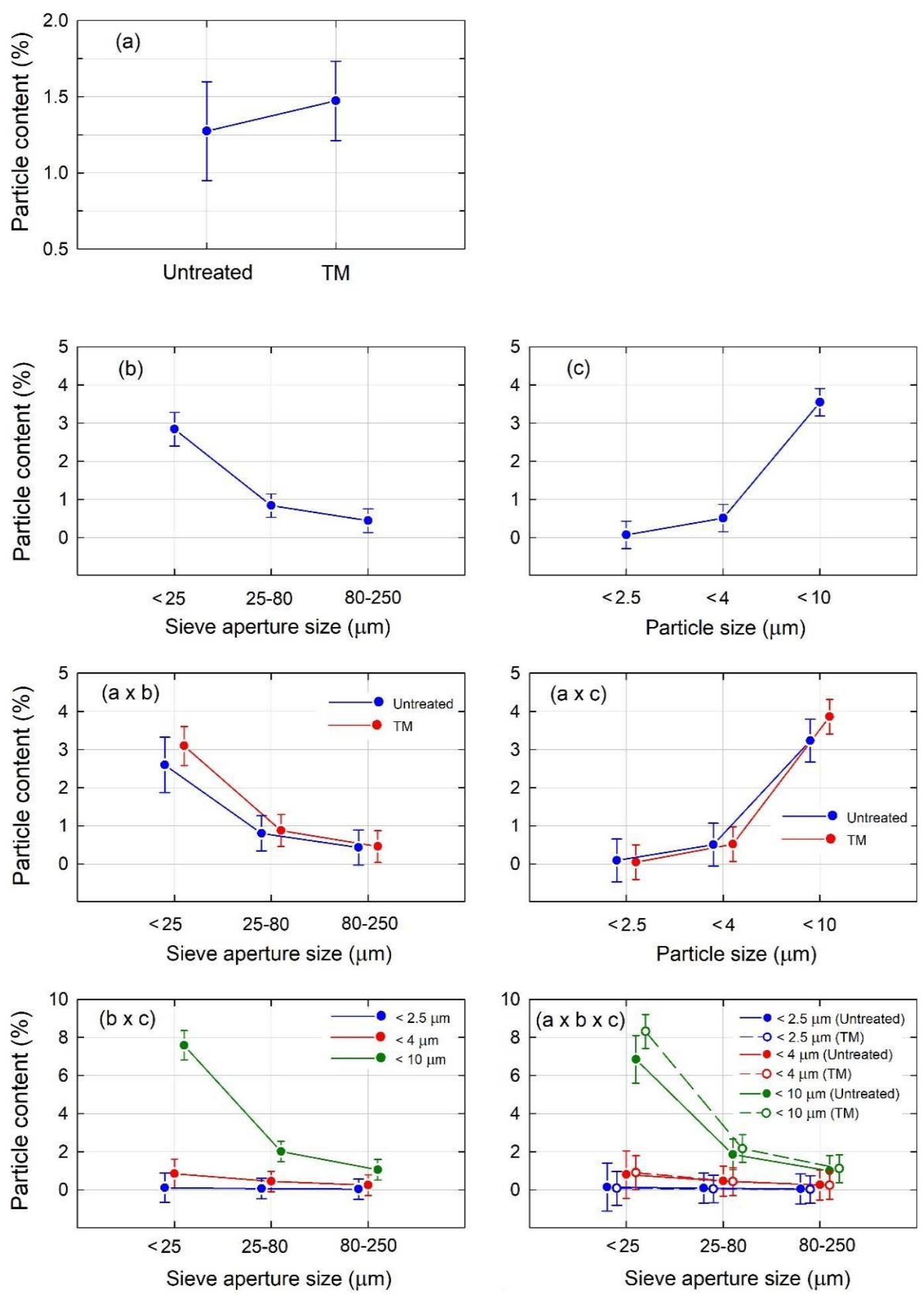

Fig. 3. Graphic illustration of the results of the analysis of variance: a) heat treatment; b) aperture size of the sieve; and c) particle size (note: error bars depicted $\pm 95 \%$ confidence limits)

The results of the variance analysis confirmed the nonsignificant influence of the heat treatment (a) on the content of the finest, potentially respirable particles in the corresponding fractions of both tested beechwood dust samples (for p-value is less than 0.05). The content of the finest dust particles, i.e., smaller than $2.5,4$, and $10 \mu \mathrm{m}$, 
significantly depended (for p-value is less than 0.05) on other factors included in the analysis, i.e., the size of the sieve aperture (b) and the size of the particles (c). Moreover, the results of the variance analysis confirmed the existence of a strong interaction of factors (b) and (c), i.e., the size of the sieve aperture and the size of the particles. A graphical representation of the performed analysis of variance is shown in Fig. 3 .

Table 2 shows the experimental data and the results of the direct comparisons (Tukey's HSD test) of the average content of the finest, potentially respirable, particles in the untreated and thermally modified beech wood dust fractions. All investigated fractions of the two tested types of wood dust had a different finest particles content. The average proportion of particles smaller than $2.5,4$, and $10 \mu \mathrm{m}$ in all tested dust fractions was within the following ranges: $0.02 \%$ to $0.14 \%, 0.23 \%$ to $0.89 \%$, and $0.99 \%$ to $8.31 \%$, respectively.

The untreated wood dust contained approximately twice the amount of finest particles (less than $2.5 \mu \mathrm{m}$ ) compared to the thermally modified wood dust. This result was recorded for each of the three tested dust fractions (less than $25 \mu \mathrm{m}, 25$ to $80 \mu \mathrm{m}$, and 80 to $250 \mu \mathrm{m}$ ). In contrast, untreated wood dust had a lower average particle content of less than $4 \mu \mathrm{m}$ and $10 \mu \mathrm{m}$ compared to the average particle content of the thermally modified wood dust. In all cases analyzed, the average content of the smallest particles (smaller than $10 \mu \mathrm{m}$, i.e., smaller than the aperture size) was calculated. The less than $25 \mu \mathrm{m}$ and 80 to $250 \mu \mathrm{m}$ fractions of both tested dusts had the highest and lowest amounts of the finest particles, respectively.

Table 2. Average Values of the Fine Particle Content (\%) of the Untreated and Thermally Modified Beech Wood Dusts with Respects to the Sieve Aperture Size and Particle Size

\begin{tabular}{|c|c|c|c|c|}
\hline $\begin{array}{c}\text { Treatment } \\
\text { Option }\end{array}$ & $\begin{array}{c}\text { Sieve Aperture } \\
\text { Aize }(\mu \mathrm{m})\end{array}$ & $<2.5 \mu \mathrm{m}$ & $<4 \mu \mathrm{m}$ & $<10 \mu \mathrm{m}$ \\
\hline \multirow{3}{*}{\begin{tabular}{c} 
Untreated \\
\cline { 2 - 4 }
\end{tabular}} & $<25$ & $0.14^{\mathrm{a}} \pm 0.08$ & $0.80^{\mathrm{a}} \pm 0.49$ & $6.85^{\mathrm{b}} \pm 5.44$ \\
\cline { 2 - 5 } & 25 to 80 & $0.09^{\mathrm{a}} \pm 0.04$ & $0.46^{\mathrm{a}} \pm 0.01$ & $1.86^{\mathrm{ab}} \pm 1.21$ \\
\cline { 2 - 5 } & 80 to 250 & $0.04^{\mathrm{a}} \pm 0.01$ & $0.25^{\mathrm{a}} \pm 0.08$ & $0.99^{\mathrm{a}} \pm 0.45$ \\
\hline \multirow{2}{*}{$\begin{array}{c}\text { Thermally } \\
\text { modified }\end{array}$} & $<25$ & $0.07^{\mathrm{c}} \pm 0.01$ & $0.89^{\mathrm{b}} \pm 0.17$ & $8.31^{\mathrm{b}} \pm 2.05$ \\
\cline { 2 - 5 } & 25 to 80 & $0.04^{\mathrm{b}} \pm 0.00$ & $0.42^{\mathrm{a}} \pm 0.14$ & $2.16^{\mathrm{a}} \pm 0.36$ \\
\cline { 2 - 5 } & 80 to 250 & $0.02^{\mathrm{a}} \pm 0.00$ & $0.23^{\mathrm{a}} \pm 0.07$ & $1.11^{\mathrm{a}} \pm 0.52$ \\
\hline
\end{tabular}

Note: Mean value $(n=6) \pm$ standard deviation; identical superscripts $(a, b, c)$ do not indicate a significant difference ( $p$-value less than 0.05 ) between mean values according to the post hoc Tukey's HSD post hoc test

The results of the post-hoc Tukey`s (HSD) test for the finest particle content for the investigated fractions of both dust types are presented in Fig. 4. The significance of the differences in the average of the finest particle content values in the individual analyzed dust fractions was denoted using superscripts a and b. Identical superscripts represent nonsignificant differences between the analyzed values.

In most of the analyzed cases, it was confirmed that there was a non-significant difference in the average content of the finest particles in the fractions of dust from the untreated wood and thermally modified wood samples (for p-value equals 0.05). A statistically significant difference in the average fine particle contents for the untreated and thermally modified dusts was confirmed only for particles less than $2.5 \mu \mathrm{m}$ occurring in the 25 to $80 \mu \mathrm{m}$ and 80 to $250 \mu \mathrm{m}$ fractions (as shown in Fig. 4). 


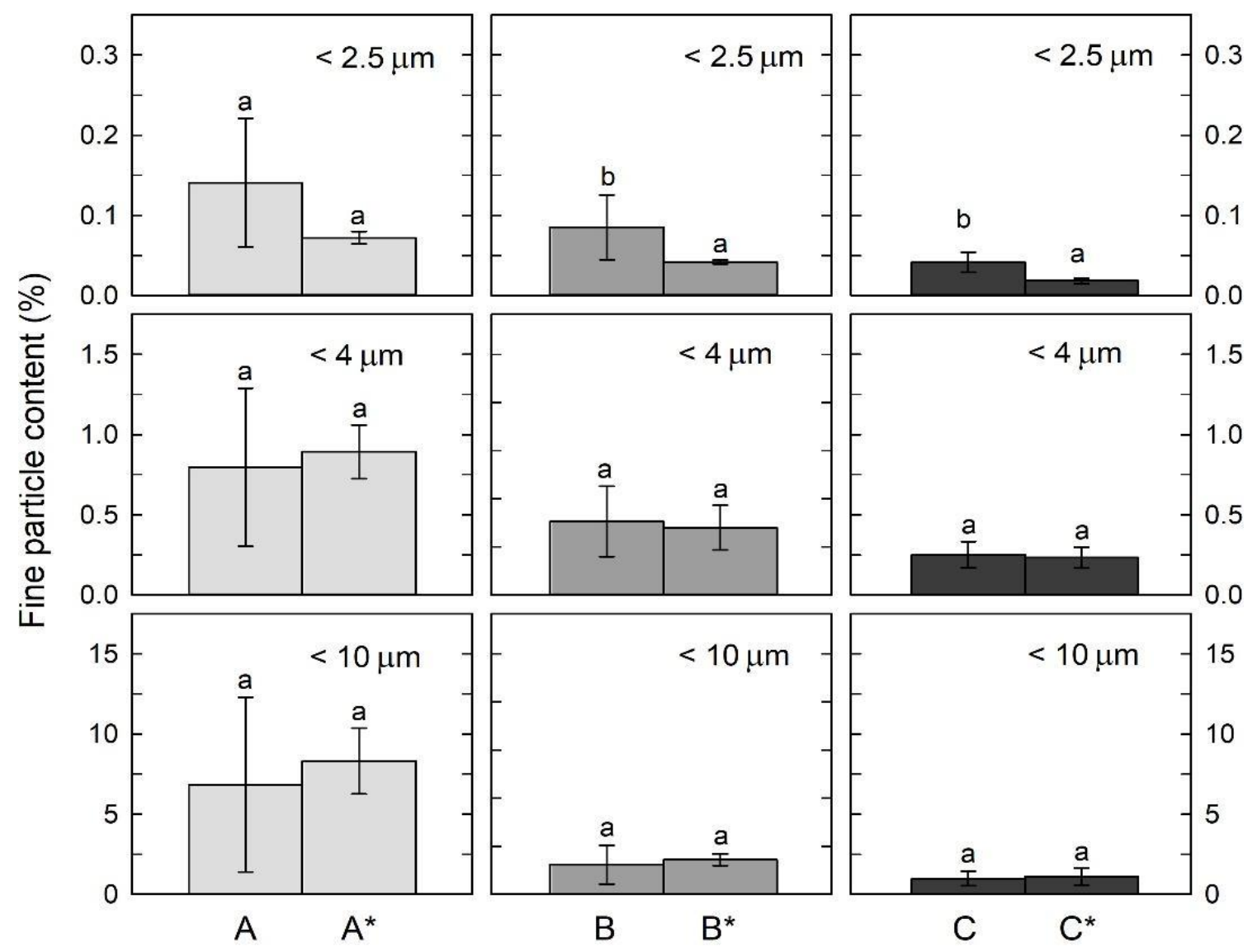

Fig. 4. Comparison of the average content of the finest particles in the untreated and thermally modified beech wood dust fractions: A) fraction less than $25 \mu \mathrm{m}$; B) fraction $25 \mu \mathrm{m}$ to $80 \mu \mathrm{m}$; and C) fraction $80 \mu \mathrm{m}$ to $250 \mu \mathrm{m}$ (Note: * indicates the fraction of thermally modified wood; identical superscripts ( $a$ and $b$ ) denote no significant differences for a $p$-value is less than $0.05 ; n=6$; and error bars depicted \pm standard deviation)

\section{Discussion}

As it is known in the case of wood dusts, the concern of industrial hygienists is more for the carcinogenic coarse particles exposure than for the fine particles exposure. Therefore this research is the study with respect to the physical properties and mechanisms of wood dusts generation but not health hazard study by wood dust. The results of this study showed that it is not possible to completely separate the individual dust fractions using a set of sieves. In the 25 to $80 \mu \mathrm{m}$ and 80 to $250 \mu \mathrm{m}$ fractions (retained on the $25 \mu \mathrm{m}$ and $80 \mu \mathrm{m}$ sieves) there were also particles with a particle size less than $10 \mu \mathrm{m}$. For this reason, the sieve analysis method can only be used for a preliminary assessment of the dust dimensional structure. The content of the smallest particles which, after dispersion in the air, can penetrate the human respiratory tract, should be determined by other methods. Therefore, in the described research, the laser diffraction analysis method was used in addition to the sieve method, which allowed the presence of particles with a particle size of less than $2.5 \mu \mathrm{m}$, less than $4 \mu \mathrm{m}$, and less than $10 \mu \mathrm{m}$ to be confirmed in all sieve fractions of the two types of wood dust tested.

This was the first attempt to measure the content of very fine particles in the wood dust from thermally modified wood. So far, in assessing the content of the finest particles, only the under-sieve fraction (with particles penetrating the finest sieve) had been used, if 
at all, considering that it is only this fraction that contains the finest particles. The undersieve fraction contains most of the smallest particles (Fig. 4), but their content in the sieve fractions retained on sieves with a larger aperture size cannot be ignored in the dust assessment, especially from an occupational point of view.

Two scientific papers are examples of recent sawdust tests using only sieve analysis. Kminiak et al. (2020), when examining unmodified and modified birch wood dust resulting from frame sawing and $\mathrm{CNC}$ milling, failed to detect the presence of potentially respirable fine dust in the under-screen fraction (aperture size less than $32 \mu \mathrm{m}$ ). Kminiak et al. (2021) compared the fine dust content in the treatment of wood and medium-density fiberboard (MDF). They used the finest sieve (32 $\mu \mathrm{m}$ in size) and found the presence of the finest particles in the under-sieve fraction; with a lower content in spruce, oak, and beech wood and a higher content in MDF. The results of this study indicated that if the cited authors had additionally used the laser diffraction method, they could have confirmed the presence of the finest dust.

Dzurenda et al. (2010) studied the effect of thermal modification on the particle size of oak wood. The dust was obtained during sawing with a feed speed $v_{1}$ of 0.36 $\mathrm{m} \cdot \mathrm{min}^{-1}$ and $v_{2}$ of $1.67 \mathrm{~m} \cdot \mathrm{min}^{-1}$. A set of sieves with the following mesh sizes was used for sawdust fractionation: 2000, 100, 500, 250, 125, 80, 63, and $32 \mu \mathrm{m}$. The authors found that the thermally modified oak sawdust was finer. The largest content (approximately $89.36 \%$ ) was determined in the fraction obtained after sieving through the 125 to $500 \mu \mathrm{m}$ sized sieves. The fraction from sieves with a size less than or equal to $80 \mu \mathrm{m}$ was less than $5 \%$, and no fraction was observed from the sieve with a size less than $32 \mu \mathrm{m}$. Contrary to the results of the cited authors, the results of this study did not show differences in the dimensions of the particles of both types of dust (Fig. 1). However, this may lead to the conclusion that thermal modification does not affect the degree of sanding waste after sanding and the content of the finest particles in it or that both methods used in this study did not allow such differences to be found. This shows that the use of the common sieve analysis method to assess the occupational health risk of dusts generated during wood processing is not sufficient. Therefore, further research on this problem should be carried out in order to finally exclude or confirm the influence of the thermal modification of wood on the dimensions of dust with the use of other methods.

Based on the results obtained, it was found that there were no statistical differences in the masses of the size fractions between the dust from the unmodified beech wood and the dust from the thermally modified beech wood (Fig. 1). The primary result of the research was the confirmed presence of respirable particles in each of the separated dust fractions.

Particles smaller than $2.5 \mu \mathrm{m}$, smaller than $4 \mu \mathrm{m}$, and smaller than $10 \mu \mathrm{m}$ were identified. The presence of these particles in the fraction less than $25 \mu \mathrm{m}$ was obvious; however, theoretically, such particles should not be present in the 25 to $80 \mu \mathrm{m}$ and 80 to $250 \mu \mathrm{m}$ fractions. The admixture of particles smaller than $10 \mu \mathrm{m}$ was greater for the $25 \mu \mathrm{m}$ to $80 \mu \mathrm{m}$ fraction compared with the $80 \mu \mathrm{m}$ to $250 \mu \mathrm{m}$ fraction (Fig. 4 ).

\section{CONCLUSIONS}

1. The dust from the untreated and thermally modified beech wood was sieved in a similar way, and a set of sieves where the smallest aperture size was $25 \mu \mathrm{m}$ did not allow for the proper measurement and comparison of the content of dust particles in both types 
of wood dust that could be suspended in the air, forming a respirable hazardous fraction.

2. Sieve analysis alone does not completely fractionate the beechwood dust into fractions of certain sizes, i.e., particles smaller than $10 \mu \mathrm{m}$ were found in each fraction. This may be the result of the temporary combination of the finest particles with large particles due to electrostatic forces, the admixture of moisture and other caking substances, or other factors temporarily agglomerating dust particles.

3. The use of the laser diffraction analysis method may be necessary to correctly assess the level of occupational health risk in the surroundings of a workstation equipped with a wood sander.

4. The exposure to fine wood dust emissions generated from sanding both untreated and thermally modified beechwood should be regarded as a significant occupational risk to the safety and health of workers in the wood-processing industry.

\section{ACKNOWLEDGMENTS}

The authors are grateful for the support of the projects by the Slovak Research and Development Agency under contract No. APVV-18-0378, APVV-19-0269, VEGA 1/0324/21, and KEGA 026UMB-4/2021. The study was also supported by the funding for statutory R\&D activities as the research task No. 506.227.02.00 of the Faculty of Forestry and Wood Technology, Poznań University of Life Sciences and the funding for PhD students and young researchers at the Faculty of Forestry and Wood Technology, Poznan University of Life Sciences.

\section{Authors' Contributions}

Conceptualization, T.R.; methodology, T.R, and J.M.; validation, J.M.; formal analysis, J.M.; investigation, M.P.; resources, P.A., L.K., M.K.; data curation, J.M.; writing - original draft preparation, M.S., T.R. and J.M.; writing-review and editing, M.S.; visualization, J.M.; supervision, T.R.; project administration, J.M.; and funding acquisition, R.K. All authors have read and agreed to the published version of the manuscript.

\section{Data Availability Statement}

All data, models, and code generated or used during the study appear in the submitted article.

\section{Conflicts of Interest}

The authors declare no conflict of interest. The funders had no role in the design of the study; in the collection, analyses, or interpretation of data; in the writing of the manuscript, or in the decision to publish the results. 


\section{REFERENCES CITED}

Aro, M. D., Geerts, S. M., French, S., and Cai, M. (2019). "Particle size analysis of airborne wood dust produced from sawing thermally modified wood," European Journal of Wood and Wood Products 77(2), 211-218. DOI: 10.1007/s00107-01901385-z

Beljo-Lučić, R., Čavlović, A. O., and Jug, M. (2011). "Definitions and relation of airborne wood dust fractions," in: Woodworking Techniques: Proceedings of the 4th International Science Conference, Š. Barcík and J. Dvořák (ed.), Czech University of Life Sciences, Prague, Czech Republic.

Blokland, J. v., Olsson, A., Oscarsson, J., Daniel, G., and Adamopoulos, S. (2020). "Crack formation, strain distribution and fracture surfaces around knots in thermally modified timber loaded in static bending," Wood Science and Technology 54(4), 1001-1028. DOI: 10.1007/s00226-020-01190-5

Candelier, K., and Dibdiakova, J. (2021). "A review on life cycle assessments of thermally modified wood," Holzforschung 75(3), 199-224. DOI: 10.1515/hf-20200102

Čermák, P., Hess, D., and Suchomelová, P. (2021). "Mass loss kinetics of thermally modified wood species as a time-temperature function," European Journal of Wood and Wood Products 79(3), 547-555. DOI: 10.1007/s00107-020-01634-6

Dudiak, M. (2021). "Modification of maple wood colour during the process of thermal treatment with saturated water steam," Acta Facultatis Xylologiae Zvolen 63(1), 2534. DOI: 10.17423/afx.2021.63.1.03

Dzurenda, L., Orlowski, K. A., and Grzeskiewicz, M. (2010). "Effect of thermal modification of oak wood on sawdust granularity," Drvna Industrija 61(2), 89-94.

Gašparík, M., Osvaldová, L. M., Çekovská, H., and Potůçek, D. (2017). "Flammability characteristics of thermally modified oak wood treated with a fire retardant," BioResources 12(4), 8451-8467. DOI: 10.15376/biores.12.4.8451-8467

Hlásková, L., Kopecký, Z., Rousek, M., Rogoziński, T., Železný, A., and Haninec, P. (2018). "Dust emissions during sanding of thermally modified beech wood," Chip and Chipless Woodworking Processes 11(1), 51-57.

Hlásková, L., Rogoziński, T., Dolny, S., Kopecký, Z., and Jedinák, M. (2015). “Content of respirable and inhalable fractions in dust created while sawing beech wood and its modifications," Drewno 58(194), 135-146. DOI: 10.12841/wood.1644-3985.096.11

Kminiak, R., and Dzurenda, L. (2019). "Impact of sycamore maple thermal treatment on a granulometric composition of chips obtained due to processing on a CNC machining mentre," Sustainability 11(3), 1-10. DOI: 10.3390/su11030718

Kminiak, R., Kučerka, M., Kristak, L., Reh, R., Antov, P., Očkajová, A., Rogoziński, T., and Pędzik, M. (2021). "Granulometric characterization of wood dust emission from CNC machining of natural wood and medium density fiberboard," Forests 12(8), 115. DOI: $10.3390 / f 12081039$

Kminiak, R., Orlowski, K. A., Dzurenda, L., Chuchala, D., and Banski, A. (2020). "Effect of thermal treatment of birch wood by saturated water vapor on granulometric composition of chips from sawing and milling processes from the point of view of its processing to composites," Applied Sciences 10(21), 1-13. DOI: 10.3390/app10217545 
Kubš, J., Gaff, M., and Barcík, Š. (2016). "Factors affecting the consumption of energy during the milling of thermally modified and unmodified beech wood," BioResources 11(1), 736-747. DOI: 10.15376/biores.11.1.736-747

Kučerka, M., and Očkajová, A. (2018). "Thermowood and granularity of abrasive wood dust," Acta Facultatis Xylologiae Zvolen 60(2), 43-51. DOI: 10.17423/afx.2018.60.2.04

Makovicka Osvaldova, L., Kadlicova, P., and Rychly, J. (2020). "Fire characteristics of selected tropical woods without and with fire retardant," Coatings 10(6), 527. DOI: 10.3390/coatings 10060527

Marková, I., Mračková, E., Očkajová, A., and Ladomerský, J. (2016). "Granulometry of selected wood dust species of dust from orbital sanders," Wood Research 61(6), 983992.

Očkajová, A., Barcík, Š., Kučerka, M., Koleda, P., Korčok, M., and Vyhnáliková, Z. (2019). "Wood dust granular analysis in the sanding process of thermally modified wood versus its density," BioResources 14(4), 8559-8572. DOI:

10.15376/biores.14.4.8559-8572

Očkajová, A., Kučerka, M., Kminiak, R., and Rogoziński, T. (2020b). “Granulometric composition of chips and dust produced from the process of working thermally modified wood," Acta Facultatis Xylologiae Zvolen 62(1), 103-111. DOI: 10.17423/afx.2020.62.1.09

Očkajová, A., Kučerka, M., Kminiak, R., Krišt’ák, L., Igaz, R., and Réh, R. (2020a). "Occupational exposure to dust produced when milling thermally modified wood," International Journal of Environmental Research and Public Health 17(5), 1-14. DOI: 10.3390/ijerph17051478

Očkajová, A., Kučerka, M., Krišt’ák, L., and Igaz, R. (2018). “Granulometric analysis of sanding dust from selected wood species," BioResources 13(4), 7481-7495. DOI: 10.15376/biores.13.4.7481-7495

Olek, W., Majka, J., and Czajkowski, Ł. (2013). "Sorption isotherms of thermally modified wood," Holzforschung 67(2), 183-191. DOI: 10.1515/hf-2011-0260

Osvaldová, L. M., and Osvald, A. (2013). "Flame retardation of wood," Advanced Materials Research 690-693, 1331-1334. DOI: 10.4028/www.scientific.net/AMR.690-693.1331

Pędzik, M., Rogoziński, T., Majka, J., Stuper-Szablewska, K., Antov, P., Kristak, L., Kminiak, R., and Kučerka, M. (2021). "Fine dust creation during hardwood machine sanding," Applied Sciences 11(14), 1-11. DOI: 10.3390/app11146602

Pędzik, M., Stuper-Szablewska, K., Sydor, M., and Rogoziński, T. (2020). "Influence of grit size and wood species on the granularity of dust particles during sanding," Applied Sciences 10(22), 1-9. DOI: 10.3390/app10228165

Pelaez-Samaniego, M. R., Yadama, V., Lowell, E., and Espinoza-Herrera, R. (2013). “A review of wood thermal pretreatments to improve wood composite properties," Wood Science and Technology 47(6), 1285-1319. DOI: 10.1007/s00226-013-0574-3

Piernik, M., Rogoziński, T., Krauss, A., and Pinkowski, G. (2019). "The influence of the thermal modification of pine (Pinus sylvestris L.) wood on the creation of fine dust particles in plane milling: Fine dust creation in the plane milling of thermally modified pine wood," Journal of Occupational Health 61(6), 481-488. DOI: 10.1002/1348-9585.12075 
Rogoziński, T., Wilkowski, J., Górski, J., Czarniak, P., Podziewski, P., and Szymanowski, K. (2015). "Dust creation in CNC drilling of wood composites," BioResources 10(2), 3657-3665. DOI: 10.15376/biores.10.2.3657-3665

Sydor, M., Mirski, R., Stuper-Szablewska, K., and Rogoziński, T. (2021). "Efficiency of machine sanding of wood," Applied Sciences 6(11), 1-12. DOI: 10.3390/app11062860

ThermoWood (2021). ThermoWood ${ }^{\circledR}$ Handbook, International Thermowood Association, Helsinki, Finland.

Vidholdová, Z., Ciglian, D., and Reinprecht, L. (2021). "Bonding of the thermally modified Norway spruce wood with the PUR and PVAc adhesives," Acta Facultatis Xylologiae Zvolen 63(1), 63-73. DOI: 10.17423/afx.2021.63.1.06

Article submitted: August 25, 2021; Peer review completed: October 15, 2021; Revised version received and accepted: October 19, 2021; Published: November 2, 2021.

DOI: $10.15376 /$ biores.17.1.7-20 